\title{
Gambaran hasil pemeriksaan fungsi hati pada anak dengan infeksi dengue periode Januari 2011-Oktober 2016 di RSUP Prof. Dr. R. D. Kandou Manado
}

\author{
${ }^{1}$ Rindah M. Saudo \\ ${ }^{2}$ Novie H. Rampengan \\ ${ }^{2}$ Jose M. Mandei
}

\author{
${ }^{1}$ Kandidat Skripsi Fakultas Kedokteran Universitas Sam Ratulangi Manado \\ ${ }^{2}$ Bagian Ilmu Kesehatan Anak Fakultas Kedokteran Universitas Sam Ratulangi Manado \\ Email: rindah.saudo@gmail.com
}

\begin{abstract}
Dengue infection still one of the global health problem. Hepatic dysfunction is common in dengue infection and the spectrum of liver dysfunction in children with dengue infection is wide and has been associated with disease severity. Hepatic dysfunction can be measured with aminotransferase levels. Significant rise of aminotransferase level helps in recognition of severe form of dengue infection. This study aimed to obtain the profile of aminotransferase levels of children diagnosed with dengue infection. This was a descriptive retrospective study using medical record data of patients in Pediatrics Department Prof. Dr. R.D. Kandou Hospital Manado. There were 432 patients with dengue infection during the period 2011-2016. Patients performed liver function test were 222 patients, however, only 183 patients that meet the inclusion criteria. All cases were grouped into Dengue Fever (DF), Dengue hemorrhagic fever (DHF) and Dengue shock syndrome (DSS) according to WHO criteria. Most patient diagnosed with DSS. Aminotransferase levels rise more significant in DSS and DHF group compared to DF group. AST was elevated more than ALT.
\end{abstract}

Keywords: dengue infection, children, liver function, AST, ALT

\begin{abstract}
Abstrak: Infeksi dengue masih merupakan masalah kesehatan global. Disfungsi hati umum ditemukan pada infeksi dengue dan spektrum disfungsi hati pada anak dengan infeksi dengue luas dan berkaitan dengan keparahan penyakit. Disfungsi hati dapat diukur dengan kadar aminotransferase. Peningkatan signifikan kadar enzim transaminase dapat membantu mengenali infeksi berat virus dengue. Penelitian ini bertujuan untuk mengetahui gambaran hasil pemeriksaan fungsi hati pada anak dengan infeksi dengue. Penelitian ini adalah penelitian deskritif retrospektif dengan menggunakan data rekam medik pasien di Bagian Ilmu Kesehatan Anak RSUP Prof. Dr. R. D. Kandou Manado. Sebanyak 432 pasien infeksi virus dengue periode 2011-2016 dan yang diperiksa fungsi hati sebanyak 222 pasien, namun hanya 183 pasien yang memenuhi kriteri inklusi. Semua kasus dikelompokkan menjadi Demam Dengue (DD), Demam berdarah dengue (DBD), dan Sindroma Syok Dengue (SSD). Pasien terbanyak adalah pasien SSD. Peningkatan kadar enzim aminotransferase lebih signifikan pada kelompok SSD dan DBD dibandingkan DD. SGOT meningkat lebih tinggi dibandingkan SGPT.
\end{abstract}

Kata kunci: infeksi dengue, anak, fungsi hati, AST, ALT

Infeksi virus dengue merupakan masalah kesehatan global. Penyakit dengue terutama ditemukan di daerah tropis dengan sekitar 2,5 milyar penduduk memiliki risiko untuk terinfeksi penyakit ini. Diperkirakan setiap tahun sekitar 50 juta orang terinfeksi virus dengue, dimana 500.000 diantaranya memerlukan rawat inap dan hampir $90 \%$ 
dari pasien rawat inap tersebut adalah anakanak. ${ }^{1}$

Menurut World Health Organization (WHO), insiden demam berdarah dengue (DBD) di dunia meningkat dari 2,2 juta kasus pada tahun 2010 menjadi 3,2 juta kasus pada tahun 2015. Kasus yang dilaporkan di Amerika, Asia Tenggara dan Pasifik Barat meningkat dari 1,2 juta pada tahun 2008 menjadi 3,2 juta kasus pada tahun 2015. Pada tahun 2015, 2,35 juta kasus infeksi dengue dilaporkan terjadi di Amerika yang 10.200 diantaranya merupakan kasus berat dan menyebabkan 1181 orang meninggal dunia. Pada tahun 2015, terjadi lonjakan kasus infeksi dengue. Di Filipina dilaporkan lebih dari 169.000 kasus, di Malaysia dilaporkan 111.000 kasus suspek dengue dan di Brazil sebanyak 1,5 juta kasus dilaporkan. ${ }^{2}$

Di Indonesia, terdapat 150.000 kasus DBD yang dilaporkan pada tahun 2007 yang lebih dari 25.000 diantaranya terjadi di DKI Jakarta dan Jawa Barat. tercatat pada bulan Januari - Februari 2016 sebanyak 8.487 orang penderita DBD dengan jumlah kematian 108 orang dengan golongan yang paling banyak menderita DBD di Indonesia adalah usia 5 - 14 tahun $(43,44 \%) .{ }^{3,4}$ Menurut data dari Dinas Kesehatan Provinsi Sulawesi Utara, dari Januari - Maret 2016 terdapat 728 kasus DBD dan untuk Kota Manado, data dari Dinas Kesehatan Kota Manado, pada bulan Januari - Februari 2016 terdapat 60 kasus DBD.

Demam berdarah merupakan penyakit yang disebabkan oleh virus dengue yang ditularkan melalui gigitan nyamuk Stegomiya aegipty (dulu disebut Aedesaegipty) dan Stegomiya albopictus (dulu disebut Aedes albopictus). World Health Organization (WHO) (1997) mengklasifikasikan DBD menurut derajat keparahan penyakit menjadi 4 golongan, yaitu derajat I - IV, dimana derajat III dan IV dikelompokkan sebagai sindrom syok dengue (SSD). ${ }^{4,5}$ Salah satu gejala dari DBD adalah hepatomegali dan disfungsi hati. Disfungsi hati yang terjadi pada infeksi dengue dapat merupakan efek langsung dari toksisitas virus atau disregulasi respon imun terhadap infeksi virus. Spektrum disfungsi hati pada anak dengan infeksi dengue sangat luas dan berhubungan dengan keparahan penyakit, yaitu dari yang ringan berupapeningkatan enzim transaminase hati (AST/ALT) sampai yang berat berupa gagal fungsi hati. ${ }^{6}$

Peningkatan enzim transaminase terjadi pada lebih dari $60 \%$ anak dengan infeksi dengue. ${ }^{7}$ Dalam sebuah studi klinis didapatkan bahwa insiden terjadinya disfungsi hati lebih banyak terjadi pada kelompok SSD dan DBD dibandingkan kelompok DD. Peningkatan level SGOT/SGPT lebih signifikan terjadi pada kelompok SSD dan DBD yaitu dapat mencapai 10 kali nilai normal, hal ini menunjukkan bahwa anak lebih berisiko untuk terkena disfungsi hati dibandingkan orang dewasa. ${ }^{8}$ Selain itu, terapi penggantian cairan pada anak dengan infeksi dengue biasanya ringer laktat (RL) yang dimetabolisme di hati dan merupakan kontraindikasi digunakan untuk pasien yang disfungsi hati, sedangkan cairan ringer asetat (Asering) yang mengandung asetat dimetabolisme di otot sehingga tidak memengaruhi fungsi hati.

Penelitian ini bertujuan untuk mengetahui gambaran hasil pemeriksaan fungsi hati pada anak dengan infeksi dengue periode Januari 2011 - Oktober 2016 di RSUP Prof. Dr. R. D. Kandou Manado.

\section{METODE PENELITIAN}

Penelitian ini merupakan penelitian deskriptif retrospektif yang dilakukan di Bagian Ilmu Kesehatan Anak RSUP Prof. Dr. R.D. Kandou Manado. Penelitian ini dilakukan pada bulan Agustus sampai November 2016.

Populasi penelitian adalah anak yang terdiagnosis infeksi dengue periode Januari 2011 - Oktober 2016 yang di rawat inap di Bagian Ilmu Kesehatan Anak RSUP Prof. Dr. R. D. Kandou Manado dengan kriteria inklusi yaitu anak usia 1 bulan - 18 tahun dengan diagnosis infeksi dengue (DD, 
DBD, SSD) yang dilakukan pemeriksaan fungsi hati. Kriteria eksklusi yaitu anak dengan infeksi dengue dengan riwayat penyakit hati.

Fungsi hati adalah sekelompok tes darah yang dilakukan untuk mengukur enzim atau protein tertentu dalam darah, umumnya dilakukan untuk membantu mendeteksi menilai atau memantau penyakit, dinyatakan dalam nilai SGPT/SGOT. Nilai normal untuk SGOT adalah <33 U/L dan nilai normal SGPT adalah <43 U/L. Infeksi dengue adalah penyakit yang disebabkan oleh virus Dengue yang di tularkan melalui gigitan nyamuk Stegomiya aegipty (dulu disebut Aedesaegipty) dan Stegomiya albopictus (dulu disebut Aedes albopictus), meliputi DD, DBD, dan SSD.

Data pasien yang dicatat meliputi identitas pasien (nama, usia, jenis kelamin, tanggal masuk), diagnosis, dan hasil pemeriksaan fungsi hati (SGOT dan SGPT). Data diolah dan disajikan dalam bentuk table dan persentase.

\section{HASIL PENELITIAN}

Sebanyak 432 anak yang terdiagnosis infeksi virus dengue dan 222 anak diantaranya diperiksa fungsi hati, namun hanya 183 anak yang memenuhi kriteria inklusi. Dari 183 anak didapatkan usia terbanyak 6-10 tahun dan menurut jenis kelamin tidak terdapat perbedaan antara anak laki-laki (49,7\%) dengan anak perempuan (50,3\%). Kelompok usia terbanyak ditemukan adalah usia 6-10 tahun $(41,5 \%)$ dan terendah usia $<1$ tahun $(4,4 \%)$. Ini dapat dilihat pada Tabel 1 .

Tabel 1. Distribusi karakteristik pasien berdasarkan jenis kelamin dan usia.

\begin{tabular}{lcc}
\hline & $\mathrm{N}$ & $\%$ \\
\hline Jenis Kelamin & 91 & 49,7 \\
Laki - laki & 92 & 50,3 \\
Perempuan & & \\
Usia & & \\
$<1$ tahun & 8 & 4,4 \\
$1-5$ tahun & 64 & 35 \\
$6-10$ tahun & 76 & 41,5 \\
$>10$ tahun & 35 & 19,1 \\
\hline
\end{tabular}

Dari 183 sampel penelitian, ditemukan terbanyak pasien terdiagnosis SSD $(49,7 \%)$ dan yang terendah DD (14,2\%). Ini dapat dilihat pada tabel 2 .

Tabel 2. Distribusi sampel berdasarkan keparahan penyakit.

\begin{tabular}{ccc}
\hline Diagnosis & $\mathrm{N}$ & $\%$ \\
\hline DD & 26 & 14,2 \\
DBD & 66 & 36,1 \\
SSD & 91 & 49,7 \\
\hline
\end{tabular}

Pada penelitian ini ditemukan peningkatan aminotransferase lebih signifikan pada SSD dan DBD dibandingkan DD dan ditemukan nilai SGOT meningkat lebih tinggi dibandingkan nilai SGPT. Ini dapat dilihat pada Tabel 3.

Tabel 3. Gambaran hasil pemeriksaan fungsi hati berdasarkan keparahan penyakit

\begin{tabular}{cccc}
\hline & DD $(\mathbf{n}=\mathbf{2 6})$ & DBD $(\mathbf{n = 6 6})$ & SSD $(\mathbf{n = 9 1})$ \\
\hline SGOT & & & \\
Meningkat & $26(100 \%)$ & $62(93,9 \%)$ & $88(96,7 \%)$ \\
Rerata & $77,19 \pm 37,80$ & $122,38 \pm 103,42$ & $208,04 \pm 279,74$ \\
Range & $36-164$ & $20-681$ & $13-1552$ \\
& & & \\
SGPT & $7(26,9 \%)$ & $24(36,4 \%)$ & $47(51,6 \%)$ \\
Meningkat & $36,96 \pm 40,18$ & $53,02 \pm 56,28$ & $84,76 \pm 123,86$ \\
Rerata & $11-217$ & $11-325$ & $9,2-734$ \\
Range & & & \\
\hline
\end{tabular}


Pada penelitian ini, berat ringannya disfungsi hati dibagi menjadi ringan (peningkatan $<3$ kali normal), sedang (3-10 kali normal), dan berat $(>10 \text { kali normal })^{9}$ dan ditemukan peningkatan berat (>10 kali nilai normal) paling banyak ditemukan pada pasien SSD seperti yang terlihat pada Tabel 4.

Tabel 4. Perbandingan hasil pemeriksaan fungsi hati berdasarkan keparahan penyakit

\begin{tabular}{llccc}
\hline & & $\begin{array}{c}\text { Ringan } \\
(<3 \text { kali normal) }\end{array}$ & $\begin{array}{c}\text { Sedang } \\
(\mathbf{3 - 1 0} \text { kali normal) }\end{array}$ & $\begin{array}{c}\text { Berat } \\
\text { (>10 kali normal) }\end{array}$ \\
\hline SGOT & DD & $20(76,9 \%)$ & $6(23,1 \%)$ & $0(0 \%)$ \\
& DBD & $36(54,5 \%)$ & $27(41 \%)$ & $3(4,5 \%)$ \\
& SSD & $39(42,8 \%)$ & $40(44 \%)$ & $12(13,2 \%)$ \\
\multirow{3}{*}{ SGPT } & & & & $0(0 \%)$ \\
& DD & $25(96,2 \%)$ & $1(3,8 \%)$ & $0(0 \%)$ \\
& DBD & $62(93,9 \%)$ & $4(6,1 \%)$ & $4(4,4 \%)$ \\
\hline
\end{tabular}

\section{BAHASAN}

Dampak infeksi dengue pada hai ditunjukkan oleh hepatomegali dan peningkatan ringan hingga sedang dari kadar enzim transaminase. Pada penelitian ini, ditemukan tidak terdapat perbedaan antara pasien jenis kelamin laki-laki dan perempuan dan berdasarkan usia, kelompok usia yang paling banyak terinfeksi dengue adalah usia 6-10 tahun, hal ini dikarenakan aktivitas dari anak usia tersebut banyak berada diluar ruangan, sehingga kemungkinan tergigit nyamuk Aedes Aegipty lebih tinggi. Ditemukan juga, pasien yang terbanyak terdiagnosis SSD $(49,7 \%)$, hal ini karena terjadi syok pada SSD yang merupakan indikasi untuk dirawat inap. Dari 183 sampel pada penelitian ini ditemukan peningkatan SGOT, yaitu $100 \%$ pada kelompok DD, 93,9\% pada kelompok DBD, dan 96,7\% pada SSD. Peningkatan SGPT didapatkan sebesar 26,9\% pada kelompok DD, 26,7\% pada DBD, dan 51,6\% pada SSD. Hasil ini sama seperti penelitian sebelumnya, ditemukan peningkatan enzim transaminase hati pada infeksi virus dengue berkisar antara 36,4\%-96\% pada anak dan dewasa. ${ }^{10,11}$

Pada penelitian ini ditemukan peningkatan enzim transaminase $>10$ kali nilai normal lebih banyak ditemukan pada DBD dan SSD dibandingkan dengan DD, yang sama seperti penelitian sebelumnya.
8,11,12,13 Pada penelitian yang dilakukan di Brazil, dari 1586 kasus infeksi dengue, peningkatan SGOT dan SGPT terlihat pada $63,4 \%$ dan $45 \%$ pasien dengan $3,8 \%$ kasus meningkat $>10$ kali nilai normal enzim transaminase. ${ }^{11}$ Hal ini menunjukkan anak memiliki resiko tinggi untuk mengalami gangguan fungsi hati. Peningkatan kadar enzim transaminase dapat menjadi penanda potensial untuk membedakan infeksi virus dengue dari infeksi virus lain selama fase demam. ${ }^{12}$ Deteksi dini dari peningkatan enzim transaminase pada pasien dengue sangat penting untuk mencegah terjadinya salah satu komplikasi infeksi dengue yaitu hepatik ensefalopati. ${ }^{14}$

Pada penelitian ini juga ditemukan peningkatan dari nilai SGOT lebih tinggi dibanding SGPT, yang sama seperti penelitian sebelumnya. ${ }^{7,8,13,15,16}$ Pada penelitian yang dilakukan di India dan Iran ditemukan nilai SGOT lebih tinggi dibandingkan dengan nilai SGPT. ${ }^{7,8} \mathrm{Hal}$ ini disebabkan karena SGOT selain ditemukan di hati, ditemukan juga di eritrosit, oto skeletal, otot jantung, ginjal dan jaringan otak, sedangkan SGPT secara spesifik dilepaskan oleh hepatosit. ${ }^{16}$ Dalam sebuah penelitian ditemukan bahwa jantung dan otot skeletal merupakan salah satu organ target infeksi dengue. ${ }^{17,18}$ Pada penelitian yang dilakukan di India, didapatkan korelasi antara angka mortalitas dengan derajat disfungsi hati pada anak dengan 
infeksi dengue. ${ }^{14,19,20 .}$ Yang menarik untuk dicatat adalah tidak terdapat perbedaan signifikan secara statistic pada rerata hasil pemeriksaan enzim transaminase pada kelompok DD, DBD, dan SSD yang sama dengan hasil penelitian sebelumnya. ${ }^{8}$

Ensefalopati dengue merupakan salah satu komplikasi neurologis yang diakibatkan oleh infeksi virus dengue. Semua serotype virus dengue dapat menjadi penyebab ensefalopati dengue, namun serotype yang paling banyak dilaporkan menyebabkan gangguan neurologis berat adalah DEN-2 dan DEN3. ${ }^{21}$ Gangguan pada susunan saraf pusat (SSP) dapat merupakan akibat sekunder dari vasculitis dan sindroma kebocoran kapiler yang mengakibatkan kebocoran plasma, edema serebral, hipoperfusi, hiponatremia, gagal hati atau gagal ginjal. Namun, menurut laporan hasil isolasi SSP menunjukkan infeksi langsung virus pada SSP. ${ }^{20,21}$ Ensefalopati dengue menunjukkan gangguan SSP berupa penurunan kesadaram menjadi apatis atau somnolen, dapat disertai kejang. ${ }^{22}$

\section{SIMPULAN}

Dari hasil penelitian dan bahasan dapat disimpulkan bahwa Peningkatan kadar transaminase lebih signifikan pada DBD dan SSD dibanding DD. Pada infeksi dengue ditemukan peningkatan SGOT lebih tinggi dibandingkan SGPT.

\section{SARAN}

Bagi para dokter dan perawat, disarankan untuk melakukan pemeriksaan fungsi hati bagi semua pasien yang terdiagnosis infeksi dengue dan marker seperti SGOT dan SGPT dapat digunakan sebagai salah satu parameter untuk evaluasi penyakit. Dan untuk penelitian selanjutnya, disarankan untuk melakukan penelitian prospektif mengenai fungsi hati pada anak yang terinfeksi virus dengue.

\section{DAFTAR PUSTAKA}

1. Hadinegoro, SR, Moedjito I, Chairulfatah A. Pedoman diagnosis dan tatalaksana infeksi virus dengue pada anak. Jakarta:
Ikatan Dokter Anak Indonesia; 2014.

2. World Health Organization. Dengue and severe dengue. 2016. Fact Sheet. [cited 2016 Aug 15] Diakses dari : http://www.who.int/mediacentre/factsh eets/fs117/en/index/html

3. Depkes RI, 2016. Wilayah KLB DBD Ada di 11 Provinsi. [cited 2016 Aug 15] Diakses dari: http://www.depkes.go.id/article/view/1 6020900001/wilayah-klb-dbd-ada-di11-kabupaten-kota.html

4. World Health Organization. 1997. Dengue haemorragic fever: diagnosis, treatment, prevention and control. $2^{\text {nd }}$ edition. Geneva.

5. Rampengan, T. H. Penyakit infeksi tropik pada anak. Edisi 2. Jakarta: EGC; 2007.h.122-8.

6. Samanta J, Sharma V. Dengue and its effects on liver. World J Clin Cases. 2015;3(2): 125-31.

7. Khandelwal R, Khandelwal LM, Susheela C. Effect of dengue fever on serum aminotransferases in children. Int $\mathbf{J}$ Contemp Pediatr. 2016;3(2):324-7.

8. Jagadishkumar K, Jain P, Manjunath VG, Umesh L. Hepatic involvement in dengue fever in children. Iran J Pediatr. 2012;22(2):231-6.

9. Kosasih EN, Kosasih AS. Tafsiran hasil pemeriksaan laboratorium klinik. Edisi kedua. Jakarta: Karisma Publishing Group; 2008.p.303-5.

10. Kamath SR, Ranjit S. Clinical features, complications and atypical manifestations of children with severe form of dengue hemorrhagic fever in South India. Indian J Pediatr. 2006;73:889-93.

11.Souza LJ, Alves JG, Nogueira RM, Gicovate NC, Bastos DA, Siqueira EW, et al. Aminotransferase changes and acute hepatitis in patients with dengue fever: Analysis of 1585 cases. Braz J Infect Dis. 2004;8:156-63.

12. Wong $\mathbf{M}$, Shen $\mathbf{E}$. The utility of liver function tests in dengue. Ann Acad Med Singapore. 2008;37:82-3.

13. Roy A, Sarkar D, Chakraborty S, Chaudhuri J, Ghosh P, Chakraborty S. Profile of hepatic involvement by dengue virus in dengue infected children. North Am J Med Sci. 2013;5:480-5. 
14. Wiwanitkit V. Liver dysfunction in dengue infection, an analysis of the previously published Thai cases. J Ayub Med Coll Abbottabad. 2007;19(1):10-1.

15. Petdachai W. Hepatic dysfunction in children with dengue shock syndrome. 2005. Dengue Bulletin.h.112-6.

16. Bandyopadhyay D, Chattaraj S, Hajra A, Mukhopadhyay S, Ganesan V. Journal of Clinical and Dagnostic Research. 2016;10(5):21-6.

17. Chhina RS, Goyal O, Chhina DK, Goyal P, Kumar R, Puri S. Liver function tests in patiens with dengue viral infection. Dengue Bull. 2008;32:110-7.

18. Salgado DM, Eltit JM, Mansfield K, Panqueba C, Castro D, Vega MR, et al. Heart and skeletal muscle are targets of dengue virus infection. Pediatr Infect Dis J. 2010;29(3):238-42.

19.Dhooria GS, Bhat D, Bains HS. Clinical profile and outcome in children of dengue hemorrhagic fever in north India. Iran J Pediatr. 2008;18(3):222-8.

20. Kanade T, Shah I. Dengue encephalopathy. J Vector Borne Dis. 2011;48:180-1.

21.Lum LC, Lam SK, Choy YS, George R, Harun F. Dengue encephalitis: a true entity?. Am J Trop Med Hyg. 1996;54:256-9.

22.Soedarmo SSP. Buku ajar infeksi \& pediatric tropis. Edisi kedua. Jakarta: Bagian Ilmu Kesehatan Anak FKUI; 2007.p.155-80. 